\title{
COVID-19: Considering impacts to employees and the workplace
}

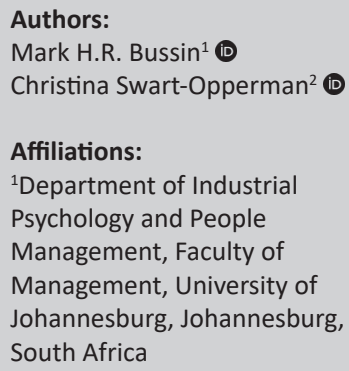

${ }^{2}$ Graduate School of Business, Faculty of Commerce, University of Cape Town Cape Town, South Africa

\section{Corresponding author:} Mark Bussin,

drbussin@mweb.co.za

Dates:

Received: 26 Apr. 2020 Accepted: 22 June 2021 Published: 20 Aug. 2021

How to cite this article: Bussin, M.H.R., \& SwartOpperman, C. (2021). COVID-19: Considering impacts to employees and the workplace. SA Journal of Human Resource

Management/SA Tydskrif vir Menslikehulpbronbestuur, 19(0), a1384. https://doi.org/ 10.4102/sajhrm.v19i0.1384

\section{Copyright:}

(C) 2021. The Authors. Licensee: AOSIS. This work is licensed under the Creative Commons Attribution License.

\section{Introduction}

The current global pandemic is a socio-economic crisis and a very emotional event that caught most businesses, globally and locally, unaware in terms of moving rapidly from a traditional corporate structure to a mostly remote workforce arrangement at best. At worst, companies have to consider their sustainability, making difficult and business-changing decisions in an unpredictable and fast-moving environment. It has become clear that the impact from the pandemic will not be short-term, but will affect countries for the years to come, changing economic development and social cohesion (Orchard, 2020). There is no aspect of life that will not be impacted in one form or another. For companies, this constant state of uncertainty and crisis management place pressure on the organisational system, impacting decisions of business strategy to people management. There is a need to balance the pressure from shareholders and those of employees; in a pandemic, which pressure takes precedence? What options exist for companies to manage the pandemic with an eye on longevity and survival? And, what opportunities exist in a 'forced change' workplace environment that may change the way companies operate from now on?

\section{As Friedman (2020) argues:}

$[T]$ he more sequestered the population is, the less efficient the economy becomes not merely for financial reasons but also because to produce things, even ideas, workers must be at their jobs, goods must be moved freely and so on. The coronavirus is frightening, but a recession that is more than just a cyclical event is also frightening, for it can extract a massive social cost as jobs are lost, banks fail and so on. The sequestration of larger and larger groups of the population cannot become a long-term feature of society without repercussions. (p. 49)

As the pandemic evolved, little preparation was possible. And even though from a technical point of view some things are manageable (at least to a reasonable extent), employees' emotions and the management thereof are a great challenge. Organisations are emotional communities with certain social networks (Robbins \& Judge, 2019) and unspoken emotional rules which impact all job behaviours, job performance as well as their customers' experience (Ashkanasy \& Ashton-James, 2005). This sense of community as well as the sociogram (Robbins \& Judge, 2019) has been broken abruptly, requiring new emotional and networking rules whilst emotional dissonance for employees is increasing.

\section{The long-term socio-economic impact of COVID-19 pandemic cannot be predicted}

The coronavirus disease 2019 (COVID-19) pandemic is clearly a Black Swan event (Taleb, 2007), unpredicted, highly improbable and with significant impact. Containing COVID-19 has led to closed borders, a severe reduction in manufacturing and an impact to the economy that are likely to result in a global recession or depression. Whilst the global financial crisis of 2008 was generally unexpected, with enormous financial impact, the COVID-19 pandemic's impact is likely to be even larger and more pervasive exacerbating poor economic performance in many countries (Kamp, 2020).

The full economic impact of the pandemic cannot be predicted and will ultimately depend on the spread and ability to contain the virus. Whilst Orchard (2020) notes that some industries may face an exponential recovery when the virus is contained, others are likely to never recover. The economic impacts are likely to result in a loss of growth because of a constrained consumption because of isolation and lack of manufacturing; a severe disruption to labour as business activity reduces, workers are retrenched or furloughed and migrant works can no longer travel and travel of goods and people stops and remains inhibited (Orchard, 2020). 
This is the 'new normal' that companies must navigate, embracing agility and innovation, adapting strategy and managing people to ensure resilience and commitment during very uncertain times.

Organisations are being forced to adapt and innovate. The argument for new ways of work has proliferated in academic and mainstream writing for decades. The COVID-19 virus has forced the hand of many organisations to adapt quickly and put into effect theories and debates on remote working, managing teams online, ensuring business continuity through technological innovation. The scale at which this is occurring provides a unique opportunity to change the world of work. The challenge is that this must be balanced against emotional upheaval, uncertainty for health and financial security, sustainability of business services and products and potential slowing in growth because of the medium-term reduction in global trade.

\section{Organisations need to manage business unusual}

Companies are making business decisions that will impact their sustainability. There is a balance between commitment to staff, and the ability to have a potential recession or depression through difficult cost-saving decisions. Companies must manage sustainability by being empathetic and compassionate to employees (Zinn, 2020). Business is being called on to stay connected to their employees, to retrench at last resort and understand the challenges employees face. At the same time, companies need to ensure that the company remains maintainable through and after the pandemic (Deloitte, no date).

Ultimate sustainability will depend on how well companies are able to manage the changes brought about by the pandemic. Are business continuity plans appropriate and reasonable? Is leadership able to manage the balance between running the business and managing people? Is communication appropriate to the situation: calm and transparent? Is reputational risk being considered by how the company is managing the pandemic?

At all of these levels, the impact on people cannot be underestimated. Executives and leaders are under considerable pressure to maintain the company. Larger organisations face stakeholder pressure to contribute towards the pandemic response financially, through business changes (possibly manufacturing health products, ensuring essential services remain operational) and by changing ways of working to accommodate isolation efforts (World Economic Forum, 2020).

Unless involved in strictly essential services (health services, banking, food retailers), individual employees, managers and teams are being asked to continue working - but doing so remotely. The constant state of unease and uncertainty of having a job will impact employee well-being, levels of commitment and loyalty. Van Hoof (09 April, 2020) calls the lockdown the biggest psychological experiment as an estimated 2.6 billion people are isolating. Van Hoof predicts that stress and burnout are likely to result, with increased absenteeism. She argues that business needs to consider the psychological impact on the mental well-being of employees. Companies need to balance these employee pressures against shareholder pressures to retain value.

\section{Managing (people) costs}

One of the most common factors business must consider under stress is cost reduction. This may result in retrenchments, furloughing employees or cutting salaries and wages (with or without associated hours of working reduction).

Maréchal, Sebastian and Puppe (2013) investigated whether wage cuts damage morale. As the authors argue, staff morale is imperative for workers to remain committed and directed towards achieving the company's goals. Wages are seen as a reflection of the morale and level of commitment. This is especially important when wages are not linked to specific outputs (e.g. a target of $x$ products sewn). The authors found that whilst wage reductions impacted morale and productivity, wage increases had no significant impact on productivity. But would this be the case when the tradeoff for employees is retrenchment? And do the co-occurring national feelings of social cohesion, staying at work, assisting society with altruism during a pandemic impact the results?

An alternative to wage cuts (which are a cut in financial remuneration without the associated cut in time) is worksharing arrangements. Work sharing is more likely to be used during a crisis such as a pandemic, when the sustainability of the company is financially at risk, but continuing productivity is essential. Work sharing includes the reduction of work hours instead of retrenchment. In this way, all workers remain in work, versus a smaller number being layed-off. Shelton (2010) argues that work-sharing arrangements may help with employee morale. The compounding impact of isolation, reduced working hours and perceived loyalty to a company during the pandemic would be interesting to ascertain. Kiviat (2009; in Shelton, 2010) argues that work sharing is preferential to retrenchments as staff who remain employed may have 'survivor guilt', impacting morale with emotional contagion and lowering productivity. It may well be the case that the impact of retrenchments on staff who remain would impact productivity and a cost-benefit analysis would need to be considered. As Shelton (2010) points out:

[F]or employers, the decision between layoffs and an arrangement combining work sharing with Short Time Compensation (STC) may rest on both financial and nonquantifiable factors such as employee morale. Some firms may find that the combination of work sharing and STC helps reduce total costs during a downturn; however, other firms may find that layoffs are more cost-effective. (p. 9) 
Time and wages are not the only consideration in managing people costs appropriately whilst ensuring employee morale and loyalty. In a pandemic, it may be the case that employees are more loyal to companies they trust or whose values they align with (Singh \& Gupta, 2015). For instance, Isenhour (2006) argues that companies should consider that employees may trade-off job prestige over pay, aligning with their cultural values. The response and adaptation to the pandemic have highlighted and forced new ways of working, some of which have been proposed for some time (Bussin, 2017).

\section{The impact to employees - psycho- social impact of COVID-19}

The most pervasive response to the pandemic has been to place countries in lockdown, to recommend or enforce isolation and to quarantine people when at high-risk of being positive to COVID-19 disease. In terms of the Affective Events Theory (Weiss \& Cropanzano, 1996), a workplace event (which the impact of the pandemic can be) usually triggers emotional reactions which are reflected in all aspects of work behaviour. The current affective event impacting individuals, groups and the organisation is the COVID-19 pandemic and the subsequent state of emergency and lockdown. The challenge managers and employees face is that they are 'working out of the office and separated from each other for the first time' (Larson, Vroman, \& Makarus, 2020, p. 1). Brooks et al. (2020), in a review of psychological literature on quarantine, concluded that the impact of isolation includes post-traumatic stress disorder, negative emotions such as anger and confusion, as well as pervasive feelings of frustration, boredom, fear (health and financial) and stigma. The authors also list mitigants of stress under isolation as communicating in a clear and transparent way with clear deadlines and rationale for the isolation, as well as mental health assistance and support. Therefore, if there is a need to make a drastic business decision, from working from home, to a reduction in salaries or hours, to business unit closures, the most important factor is to communicate the decisions and decision-making clearly from leadership to provide certainty to employees.

Certainty and trust in leadership are linked to greater loyalty and better customer service (Chen, Zhu, \& Zhou, 2014; Chuang, Judge, \& Liaw, 2012).

There are very specific challenges managers and employees might face during this period of forced separation as the emotional bonds between employees have been broken. There is reference in the literature to more stress and eventual burnout because of difficulties in lying down boundaries between home and work (Larson et al., 2020), information overload or insufficient information that lead to increased potential for conflict (Gallo, 2015), professional isolation and weakening of personal networks (Golden, Veiga, \& Dino, 2008), feelings of fear as well as self-doubt (decreased feelings of self-efficacy). Brooks et al. (2020) list the following stressors that may exist during isolation/quarantine:
- Duration of quarantine - the longer the isolation, the worse the psychological stress.

- Fear from infection of self or family members.

- Frustration and boredom linked to a change in routine, reduced contact, lack of work if unable to work virtually and reduced ability to do daily activities.

- Inadequate supplies of food, water and health supplies.

- Inadequate information because of either poor government communication, institutional communication or workplace communication.

After isolation, the following stressors were reported:

- Financial loss because of changes in work circumstance, potential change in working hours and wages.

- Stigma, especially, if one was exposed to a virus.

Brooks et al. (2020) argue that transparent and clear communication is essential, assist with supplies, ensure activities continue and promote altruism.

As emotions are contagious, it is yet unknown how online or virtual emotions in a time of crises will determine individual, team and organisational mood. It can also be expected that internet trolls could create more emotional turmoil and uncertainty. An internet troll is someone 'who enters an online discussion and posts comments almost exclusively to upset the discussants or disrupts the conversation' (Shiraev, 2017, p. 433).

\section{Virtual emotions}

Several scholars (Cascio, 2000; Clark, Karau, \& Michalisin, 2012; Hannay, 2016) reported that individuals with certain personality traits tend to be more suited to work remotely and be part of virtual teams. Similarly, not all managers have the required emotional stamina to manage and lead remotely. For example, individuals who are more introvert with a high need for achievement and a lower need for affiliation, preferring sensing in contrast to intuition and thinking instead of feeling, as well as judging instead of perceiving, seem to be more suited for working remotely. The challenge that organisations face is that employees who do not fit this description might experience increased boredom, anxiety, anger, frustration, isolation, despondency and feelings of being misunderstood. It can, therefore, be postulated that some employees adjust easily emotionally during a crises than others.

Employees' emotions and moods impact coping behaviour and mental health. This article proposes that employee's emotional reaction to the current reality could be discussed using an adjusted emotive outlook framework (SwartOpperman, 2019) to indicate which emotions could be surfacing during times of crises. An adjusted definition of emotive outlook is the emotional disposition and subsequent psychological and behavioural manifestations when faced with intra-psychological, interpersonal, team, organisational or situational challenges (see Figure 1). 
TABLE 1: Emotional constructs context and emotions emerging during crises.

\begin{tabular}{|c|c|c|c|}
\hline Emotive outlook category & Description & Context & Emotions surfacing \\
\hline 1. Emotional management (self) & $\begin{array}{l}\text { 'An individual's emotional awareness and intra- } \\
\text { physiological ability to manage emotional cues and } \\
\text { triggers' }\end{array}$ & $\begin{array}{l}\text { - Virtuosity } \\
\text { - Remote working } \\
\text { - COVID-19 } \\
\text { - Forced change } \\
\text { - New cultural norms }\end{array}$ & $\begin{array}{l}\text { - Hostility } \\
\text { - Extreme self-control } \\
\text { - Isolation } \\
\text { - Fear } \\
\text { - Anxiety } \\
\text { - Hysteria } \\
\text { - Suspicion } \\
\text { - Defensiveness-self } \\
\text { - Virtual emotions } \\
\text { - Resilience } \\
\text { - Melancholy } \\
\text { - Hardiness }\end{array}$ \\
\hline 2. Mental acuity & $\begin{array}{l}\text { This refers to mental focus despite emotional or } \\
\text { situational distractions }\end{array}$ & $\begin{array}{l}\text { - Specific task knowledge } \\
\text { - Technological acumen and resources } \\
\text { - Environmental volatility }\end{array}$ & $\begin{array}{l}\text { - Information fatigue } \\
\text { - Technostress } \\
\text { - Anger } \\
\text { - Shame }\end{array}$ \\
\hline 3. Self/Reality orientation & $\begin{array}{l}\text { This is reflected in positivity and individual } \\
\text { enablement, reflecting emotional fitness and } \\
\text { empowerment }\end{array}$ & $\begin{array}{l}\text { - Personality } \\
\text { - Spirituality } \\
\text { - Individual mood }\end{array}$ & $\begin{array}{l}\text { - Hubris } \\
\text { - Apathy } \\
\text { - Adaptability } \\
\text { - Hope } \\
\text { - Sad }\end{array}$ \\
\hline 5. Social fitness & $\begin{array}{l}\text { 'To engage in socially appropriate conversations and } \\
\text { interactions' }\end{array}$ & $\begin{array}{l}\text { - Online interactions } \\
\text { - Personality } \\
\text { - Emotional well-being }\end{array}$ & $\begin{array}{l}\text { - Uncertainty } \\
\text { - Bewilderment } \\
\text { - Feelings of irrelevance }\end{array}$ \\
\hline 6. Social sensitivity & $\begin{array}{l}\text { This involves 'emotional adeptness' and 'appropriate } \\
\text { emotional sensitivity' }\end{array}$ & $\begin{array}{l}\text { - Personal values } \\
\text { - Isolation } \\
\text { - Emotional competence } \\
\text { - Virtual communications etiquette }\end{array}$ & $\begin{array}{l}\text { - Compassion } \\
\text { - Affective ignorance } \\
\text { - Anxiety } \\
\text { - Panic } \\
\text { - Loneliness } \\
\text { - Vulnerability }\end{array}$ \\
\hline
\end{tabular}

Source: Adapted from Swart-Opperman, C. (2019). Today and beyond in strategic human resource management. In D. Viljoen (Ed.), IFR Institute for futures research: South African futures (Vol. 3 , no. 20, pp. 2-7). Stellenbosch: South Africa.

\section{Virtual teams}

A virtual team is defined by Cascio (2000) as members who interact 'through some combination of electronic communication system' (p. 83) working towards an agreed upon goal (Robbins \& Judge, 2019). Thus, collaboration is technologically enabled instead of face-to-face interaction. Virtual teaming has become a forced reality as team members, often unaccustomed and unprepared for virtual interaction. It is emphasised by Hassett, Harikkala-Laihinen, Nummela and Raits (2018) that 'managing emotions and emotionality is one of the most important challenges that organization face for Virtual Teams (VT's)' (p. 167). Ashkanasy and Ashton-James (2005) also highlight the role that emotion display in groups plays to establish groupcohesion and that 'emotional expression is an essential social process in group formation and maintenance' ( $p$. 249). It can be foreseen that the biggest challenge teams will face for the foreseeable future could be attaining cohesion and subsequent group formation and their sense of team efficacy and identity. In their qualitative single case study, 32 virtual team members were interviewed on their experienced emotions during a cross-border acquisition. They reported 'emotions as moderators of how well the VT perform' (p. 182) and that team members' 'emotions toward virtuality (technology and means of communication) and the emotions that virtuality brings may greatly affect the communication strategy' (p. 182). Even though their study focused on M\&A's, the findings apply to all VT's as trust is important for team functioning and cultural differences could cause lack of understanding and increased misunderstandings and frustrations amongst team members. Shapira (2020) also emphasises the challenge that leaders face whilst communicating to teams during periods of uncertainty and fear.

The current reality for forced virtual teams is that immediate performance is required, without being afforded the change to establish virtual relationships, laying down the rules for team member engagement or developing shared mental modes (refer to Bonebright [2010] for a complete discussion of the Tuckman and Jensen [1977] model of small group development). This is also reinforced by Salas, Priest, Stagl, Sims and Burke (2007) asserting that:

$[W]$ e do not have a good understanding of the impact that becoming 'virtual' has on team member and team processes and performance. In fact, most of what is currently known has been generalized from research with collocated teams. (p. 430)

Emotional triggers for virtual team members often arise from a lack of shared context:

[Y]ou're not sitting in the same building, experiencing the same weather, seeing the same things - it's easy to make assumptions about how your colleague feels or why he is acting the way he is. (Gallo, 2015, p. 2)

\section{Conclusion}

The COVID-19 pandemic is sure to change the way we work (The Economist, 2020). At the very least, companies are assessing their preparedness for a 'black swan' event, the impact to business continuity and how employees and customers have responded. Virtual meetings, online collaboration and agile ways of working are becoming normal 
in workplaces that can use these strategies. Organisations are finding new ways to remain connected to their customer base, ensuring that their communication is transparent and clear.

The socio-economic impact of the pandemic will last for some time, with shrinking global growth, constrained global trade, but also new areas of innovation and opportunities for fast recovery as the pandemic resolves (The Economist, 2020). As companies use this time to innovate, change ways of working, adapt and respond to the impact of the pandemic, so resilience is built.

\section{Acknowledgements Competing interests}

The authors have declared that no competing interest exists.

\section{Authors' contributions}

Both authors contributed equally to this work.

\section{Ethical considerations}

This article followed all ethical standards for a research without direct contact with human or animal subjects.

\section{Funding information}

This research received no specific grant from any funding agency in the public, commercial or not-for-profit sectors.

\section{Data availability}

Data sharing is not applicable to this article as no new data were created or analysed in this study.

\section{Disclaimer}

The views and opinions expressed in this article are those of the authors and do not reflect the official policy or position of any affiliated agency of the authors.

\section{References}

Ashkanasy, N.M., \& Ashton-James, C.E. (2005). Emotion in Organizations: A Neglected Topic in I/O, but with a bright future. In G.P. Hodgkinson \& J.K. Ford (Eds.), International review of industrial and organizational psychology (Vol. 20, pp. 221-228). London: John Wiley \& Sons.

Bonebright, D.A. (2010). 40 years of storming: A historical reviews of Tuckman's mode of small group development. Human Resource Development International, 13(1) 111-120. https://doi.org/10.1080/136788610035890999

Brooks, S.K., Webster, R.K., Smith, L.E., Woodlands, L., Wessely, S., Greenberg, N., \& Rubin, G.J. (2020). The psychological impact of quarantine and how to reduce it: Rapid review of the evidence. The Lancet, 395(10227), 912-920. https://doi. org/10.1016/S0140-6736(20)30460-8

Bussin, M. (2017). Organisation design in Uber times. Randburg: Knowledge Resources.

Cascio, W.F. (2000). Managing a virtual workplace. Academy of Management Executive, 14(3), 81-90. https://doi.org/10.5465/ame.2000.4468068

Chen, Z., Zhu, J., \& Zhou, M. (2015). How does a servant leader fuel the service fire? A multilevel model of servant leadership, individual self-identity, group competition climate, and customer service performance. Journal of Applied Psychology, 100(2), 511-521. https://doi.org/10.1037/a0038036
Chuang, A., Judge, T.A., \& Liaw, Y, J. (2012). Transformational leadership and customer service: A moderated mediation model of negative affectivity and emotion regulation. European Journal of Work and Organizational Psychology, 21(1), 28-56. https://doi.org/10.1080/1359432X.2010.532911

Clark, L.A., Karau, S.J., \& Michalisin, M.D. (2012). Telecommuting attitudes and the 'Big Five' personality dimensions. Journal of Management Policy and Practice, 13(3), 31-46.

Deloitte. (no date). COVID-19: Managing risks and ensuring business continuity Retrieved from https://www2.deloitte.com/cz/en/pages/risk/solutions/covidzajisteni-kontinuity-cinnosti.htm

Friedman, G. (2020). George Friedman's thoughts: Compromising on Corona. Retrieved from https://geopoliticalfutures.com/george-friedmans-thoughts-compromising-oncorona/

Golden, T.D., Veiga, J.F., \& Dino, R.N. (2008). The impact of professional isolation on teleworker job performance and turnover intentions: Does time spent teleworking, interacting face-to-face, or having access to communication enhancing technology matter? Journal of Applied Psychology, 93(6), 1412-1421.

Hannay, M. 2016. Telecommuting: Using personality to select candidates for alternative work arrangements. Journal of Management and Marketing Research, 20, 1-12.

Hassett, M.E., Harikkala-Laihinen, R., Nummpla, N., \& Raitis, J. (2018). Emotions and virtual teams in cross-border acquisitions. Individual, Relational, and Contextual Dynamics of Emotion in Organizations, 14, 163-187. https://doi.org/10.1108/ S1746-979120180000014016

Isenhour, L.C. (2006). The relations among cultural values, ethnicity, and job choice trade-off preferences. Unpublished doctoral dissertation. University of Central Florida, Orlando, FL.

Kamp, A. (2020). COVID-19: Economic and socila impact. In W. Crous (Eds.), Managing organisations during the COVID-19 vortex. Randburg: KR Publishing.

Larson, B.Z., Vroman, S.R., \& Makarius, E.F. (2020). A guide to managing your (newly) remote workers (pp. 1-7). Retrieved from https://hbr.org/2020/03/aguide-to-managing-your-newly-remote-workers

Maréchal, M.A., Kube, S., \& Puppe, C. (2013). Do wage cuts damage work morale? Evidence from a natural field experiment. Journal of the European Economic Association, 11(4), 853-870. https://doi.org/10.1111/jeea.12022

Orchard, P. (2020). Assessing the economic effects of the coronavirus. Retrieved from https://geopoliticalfutures.com/assessing-the-economic-effects-of-thecoronavirus/

Robbins, S.P., \& Judge, T.A. (2019). Organisational behavior (18th edn.). Harlow: Pearson Education Limited.

Salas, E., Priest, H.A., Stagl, K.C., Sims, D.E., \& Burke, C.S. (2007). Work teams in organizations: A historical reflection and lessons learned. In L.L. Koppes (Ed.) Historical perspectives in industrial and organizational psychology (Chapter 17, pp. 407-438). New York, NY: Psychological Press.

Shapira, H. (2020). How to reassure your team when the news is scary. 05 March. Retrieved from https://hbr.org/2020/03how-to-reassure-your-team-when-the-news

Shelton, A.M. (2010). Compensated work sharing arrangements (short-term compensation) as an alternative to layoffs. Congressional Research Services.
Retrieved from https://www.everycrsreport.com/files/20100203_R40689_1fddb Retrieved from https://www.everycrsreport.com
b3a8fbe7008fdbdba79e6b36d8697722bc8.pdf

Shiraev, E. (2017). Personality theories: A global view. London: Sage.

Singh, A., \& Gupta, B. (2015). Job involvement, organizational commitment, professional commitment, and team commitment: A study of generational diversity. Benchmarking, 22(6), 1192-1211. https://doi.org/10.1108/BIJ-01-2014-0007

Swart-Opperman, C. (2019). Today and beyond in strategic human resource management. In D. Viljoen (Ed.), IFR Institute for futures research: South African futures (Vol. 3, no. 20, pp. 2-7). Stellenbosch: South Africa.

Swart-Opperman, C., \& April, K. (2018). Innovation team composition: The enabling role of the individual emotive outlook. African Journal of Business Management, 12(12), 357-371. https://doi.org/10.5897/AJBM2018.8547

Taleb, N.N. (2007). The Black Swan: The impact of the highly improbable. New York, NY: Random House.

The Economist. (2020, April 11). The changes COVID-19 is forcing onto business. The Briefing. Retrieved from https://www.economist.com/briefing/2020/04/11/thechanges-covid-19-is-forcing-on-to-business

Tuckman, B.W., \& Jensen, M.A.C. (1977). Stages of small-group development revisited Group \& organization studies, 2(4), 419-427, December.

Van Hoof, E. (2020, April 9). Lockdown is the world's biggest psychological experiemet and we will pay the price. World Economic Forum. Retrieved from https://www. weforum.org/agenda/2020/04/this-is-the-psychological-side-of-the-covid-19pandemic-that-were-ignoring/

Weiss, H.M., \& Cropanzano, R. (1996). Affective events theory: A theoretical at work. Research in Organizational Behaviour. Retrieved from https://www.weforum.org/ agenda/2020/03/covid-responsible-businesses-during-the-coronavirus-pandemic/

World Economic Forum. (2020, March 20). How repsonisble business can step forward to fight coronavirus. Retrieved from https://www.weforum.org/agenda/2020/03/ covid-responsible-businesses-during-the-coronavirus-pandemic/

Zinn, S. (2020). Foreward. In W. Crous (Ed.), Managing organisations during the COVID-19 vortex. Randburg: KR Publishing. 